\title{
34. PETROGRAPHY, MINERALOGY, AND GEOCHEMISTRY OF BASALTS FROM HOLE 534A, LEG 76 ${ }^{1}$
}

\author{
John Logothetis, Department of Geology, Dalhousie University, Halifax, N. S., Canada
}

\begin{abstract}
Leg 76 sampled $31.5 \mathrm{~m}$ of basaltic basement at Deep Sea Drilling Project Hole 534A in the Blake-Bahama Basin. The basalts represent a short section of mineralogically uniform, sparsely plagioclase-phyric pillow flows, composed mainly of plagioclase, augitic clinopyroxene, iron-titanium oxides with variable amounts of alteration products (smectite \pm carbonate \pm quartz). Their major element chemistry is typical of mid-ocean ridge tholeiites and has normative compositions of olivine tholeiites. $\mathrm{Mg} /\left(\mathrm{Mg}+\mathrm{Fe}^{2+}\right)$ ratios range from 0.58 to 0.60 , which suggests that these basalts are evolved compared to primitive mantle melts.
\end{abstract}

\section{INTRODUCTION}

Hole 534A of the Deep Sea Drilling Project penetrated $31.5 \mathrm{~m}$ into the basaltic basement at $28^{\circ} 20.6^{\prime} \mathrm{N}$, $75^{\circ} 22.9^{\prime} \mathrm{W}$ in the Blake-Bahama Basin. The basal sedimentary section overlying the basement is dated as middle Callovian (154 m.y.) (Site 534 report).

The Leg 76 shipboard party undertook a visual and general petrographic description of the basaltic rocks. On the basis of texture, occurrence of glassy margins, and breccia zones, 29 cooling units of a dominantly dark gray to greenish gray aphyric basalt were identified. This study describes the petrography of the basalts and gives the results of a reconnaissance microprobe study of plagioclase and pyroxene groundmass and microphenocryst phases. Major oxide whole-rock chemistry of selected sections from the core is presented and is related to the mineralogy and crystallization history of the basalts.

\section{ANALYTICAL TECHNIQUES}

Plagioclases and pyroxenes were analyzed by electron microprobe using the energy-dispersive system (Cambridge Microscan). Natural mineral standards were used for both phases. All microprobe data were corrected according to the program EMPADR VII of Rucklidge and Gasparrini (1969).

Whole-rock determination of four samples was done by energydispersive microprobe analysis as described by MacKay (1981) on whole-rock powders fused for 15 to $20 \mathrm{~s}$ on molybdenum strips. The DPL standard (Dalhousie Mid-Ocean Pillow Lava Standard 56-2) was used as a control. Each analysis represents an average of five spot analyses, having a precision that is better than $2.0 \%$ of the amount present for all major oxides except $\mathrm{Na}_{2} \mathrm{O}$. Ferrous iron was determined by visual titration, according to the modified cold acid decomposition method of Wilson (Maxwell, 1968), and ferric iron was determined by difference. $\mathrm{P}_{2} \mathrm{O}_{5}$ was analyzed spectrophotometrically after formation of a phosphomolybdate complex and its reduction to molybdenum blue. $\mathrm{H}_{072} \mathrm{O}^{-}$and $\mathrm{H}_{2} \mathrm{O}^{+}$were determined by oven drying at $110^{\circ} \mathrm{C}$ and by modified Penfield method, respectively (Maxwell, 1968). Carbon dioxide was determined by a nonaqueous automatic titration by sodium methylate solution, following absorption in a solution of 2\% tri-ethanolamine in acetone and methanol (Sen Gupta,

\footnotetext{
${ }^{1}$ Sheridan, R. E., Gradstein, F. M., et al., Init. Repts. DSDP, 76: Washington (U.S. Govt. Printing Office).
}

1970). Analyzed whole-rock samples were selected from sections that showed the least alteration in thin section. Glass was not identified in thin section and chilled margins were completely altered to clay.

\section{PETROGRAPHY AND MINERALOGY}

The basalts of Hole 534A are aphyric to sparsely phyric with up to $5 \%$ microphenocrysts of plagioclase. The groundmass is comprised of calcic plagioclase, augitic clinopyroxene, titanomagnetite, and sulfides. Olivine was not identified in any of the thin sections examined, although shipboard studies reported the presence of several completely clay pseudomorphs after olivine. All specimens examined exhibit some degree of alteration. Smectite, carbonate, and minor quartz replace microphenocrysts and interstitial groundmass material and fill veins and vesicles. Hematite and pyrite also occur in some veins and vesicles.

\section{TEXTURE}

With increasing distance from the outer margins of pillow flows, the basalts exhibit a textural sequence consisting of an altered chilled margin, a variolitic-subvariolitic (sheaf-textured) zone, and finally a granular intersertal zone over several centimeters into the pillow interiors. Plate 1 illustrates the main textural types observed in the basalts of Hole 534A.

In sections with variolitic texture the variolites are pale brown, up to $0.5 \mathrm{~mm}$ in diameter, often bow-tie or ellipsoidal-shaped, and are composed of extremely fine intergrowths of crystalline plagioclase and pyroxene described by Bryan (1972) as typical of quenched basalts such as those from the Mid-Atlantic Ridge. Fine plagioclase crystals and microlites occur as randomly oriented crystals crosscutting variolites and as oriented acicular crystals parallel to internal variolite crystal growth. Swallow-tail plagioclase commonly merges with variolitic fiber overgrowths and appears to serve as points of nucleation (Plate 1, Fig. 1). Titanomagnetite grains are distributed along variolite boundaries and along the long direction of crystal fiber growth. With increasing crystallinity, variolitic texture is succeeded by coarsergrained, sheaf-textured, fan-shaped intergrowths of py- 
roxene and plagioclase (Plate 1 , Fig. 2). This texture, in turn, is transitional to microcrystalline, intersertal textured sections with characteristic subophitic intergrowths of plagioclase laths and pyroxene in a finer-grained groundmass of plagioclase, pyroxene, iron-titanium oxides, as well as variable amounts of altered palagonitic mesostasis.

\section{PLAGIOCLASE}

Plagioclase occurs as needlelike, acicular microlites and laths $(0.1-0.5 \mathrm{~mm})$ with simple albite twinning. In specimens with variolitic subvariolitic textures, swallowtail and skeletal plagioclase are common, whereas in coarser-grained sections plagioclase laths are intergrown and overgrown by clinopyroxene in subophitic fashion (Plate 1, Fig. 4). Microphenocrysts of plagioclase (Plate 1, Fig. 5) compose up to $5 \%$ of the examined sections and occur as equant to lath-shaped crystals in interlocking and reticulate clusters up to 2 to $3 \mathrm{~mm}$ in size, commonly with thin sodic rims.

Representative plagioclase analyses are reported in Table 1. On the basis of the anorthite component it is possible to distinguish groundmass plagioclase with uniform $\mathrm{An}_{70}$ to $\mathrm{An}_{75}$ content from the more calcic cores $\left(\mathrm{An}_{80}\right.$ to $\left.\mathrm{An}_{90}\right)$ of microphenocrysts. The microphenocryst rims are $\mathrm{An}_{75}$, approximating the composition of groundmass plagioclase. In addition, the thin sodic rims show a slight uptake of potassium with $\mathrm{K}_{2} \mathrm{O} \simeq 0.8 \%$. The composition of phenocryst cores and groundmass pairs (Table 1) shows an increase of $\mathrm{FeO}$ and $\mathrm{MgO}$ with decreasing An content.

\section{CLINOPYROXENE}

Clinopyroxene of augitic composition $\left(2 \mathrm{~V}^{\circ}=40-45^{\circ}\right)$ is much less abundant than plagioclase and appears to be absent in some sections. Clinopyroxene occurs as anhedral, granular-textured, groundmass grains and as subophitic intergrowths, with plagioclase in the coarsergrained sections. It is commonly present as anhedral to euhedral crystals up to $0.3 \mathrm{~mm}$ associated with plagioclase glomerocrysts.

Clinopyroxenes from Hole 534A lie within the compositional fields of Fe-rich endiopside and Fe-poor au-

Table 1. Representative groundmass and microphenocrystic plagioclase composition.

\begin{tabular}{|c|c|c|c|c|c|c|c|c|}
\hline \multirow[b]{3}{*}{ Component } & \multicolumn{8}{|c|}{ Sample } \\
\hline & \multicolumn{2}{|c|}{$\begin{array}{l}534 \mathrm{~A}-128-1 \\
\text { (Piece 10) }\end{array}$} & \multicolumn{2}{|c|}{$\begin{array}{l}534 \mathrm{~A}-128-3 \\
\text { (Piece 1C) }\end{array}$} & \multicolumn{2}{|c|}{$\begin{array}{l}534 \mathrm{~A}-129-5 \\
\text { (Piece 7) }\end{array}$} & \multicolumn{2}{|c|}{$\begin{array}{c}534 \mathrm{~A}-130-2 \\
\text { (Piece 6) }\end{array}$} \\
\hline & g & $\mathrm{m} \phi$ & $\mathrm{g}$ & $\mathrm{m} \phi$ & g & $\mathrm{m} \phi$ & g & $\mathrm{m} \phi$ \\
\hline $\mathrm{SiO}_{2}$ & 50.90 & 47.43 & 51.75 & 47.00 & 51.52 & 48.30 & 51.63 & 46.98 \\
\hline $\mathrm{Al}_{2} \mathrm{O}_{3}$ & 30.21 & 33.36 & 28.60 & 33.02 & 29.91 & 32.75 & 30.19 & 33.41 \\
\hline $\mathrm{MgO}^{-}$ & 0.60 & 0.15 & 0.68 & 0.12 & 0.30 & 0.08 & 0.24 & 0.18 \\
\hline $\mathrm{FeO}$ & 1.16 & 0.62 & 1.29 & 0.44 & 0.87 & 0.69 & 0.76 & 0.44 \\
\hline $\mathrm{CaO}$ & 14.54 & 17.22 & 13.52 & 17.25 & 14.31 & 16.71 & 14.13 & 17.48 \\
\hline $\mathrm{Na}_{2} \mathrm{O}$ & 2.97 & 1.49 & 3.21 & 1.25 & 3.17 & 1.76 & 3.02 & 1.13 \\
\hline $\mathrm{K}_{2} \mathrm{O}$ & 0.00 & 0.00 & 0.13 & 0.00 & 0.00 & 0.00 & 0.00 & 0.00 \\
\hline Total & 100.38 & 100.27 & 99.18 & 99.08 & 100.08 & 100.29 & 99.97 & 99.62 \\
\hline Or & & & 1 & & & & & \\
\hline$A b$ & 27 & 14 & 30 & 12 & 29 & 16 & 28 & 10 \\
\hline An & 73 & 86 & 69 & 88 & 71 & 84 & 72 & 90 \\
\hline
\end{tabular}

Note: $\mathrm{g}=$ groundmass plagioclase; $\mathrm{m} \phi=$ microphenocrystic plagioclase. gite as defined by Poldervaart and Hess (1951) (Fig. 1 and Table 2). These analyses represent only groundmass and subophitic pyroxenes, as no phenocrysts were observed. The most iron-rich specimen analyzed in these rocks is $\mathrm{Wo}_{36} \mathrm{En}_{25} \mathrm{Fs}_{39}$ (Analysis 4, Table 2) of ferroaugite composition from a minute subhedral groundmass grain. This grain is noticeably enriched in iron and aluminum, although an iron enrichment trend (as is often observed in the groundmass pyroxenes of oceanfloor basalts) is not well defined in Figure 1. Its distinctly different chemistry may be accounted for in terms of crystal-melt partitioning of elements. During crystal growth of pyroxenes of endiopside to augitic composition the immediately adjacent liquid becomes enriched in $\mathrm{Al}, \mathrm{Ti}$, and $\mathrm{Fe}$ and diluted in $\mathrm{Ca}$ and $\mathrm{Mg}$ (Huebner, 1980). Subsequent crystallization of a pyroxene from such a liquid will have the observed aluminous ferroaugite composition of Analysis 4, Table 2, and be relatively depleted in $\mathrm{Ca}$ and $\mathrm{Mg}$. The interstitial setting of this minute ferroaugite grain relative to immediately adjacent subophitic clinopyroxenes of endiopside to augite composition supports this interpretation.

\section{OPAQUE OXIDES}

Iron-titanium oxides occur only as groundmass phases, as euhedral crystals of skeletal and cruciform habit distributed along the outer boundary or outlines of variolites, and as inclusions in brown, altered mesostasis. In reflected light, individual crystals are commonly corroded with an outer brownish alteration rim.

\section{VESICLES}

Vesicles of up to $1 \mathrm{~mm}$ in size comprise 1 to $5 \%$ of all examined sections and are filled with smectite, \pm calcium carbonate, \pm quartz. Vesicle and vein-filling clay mineralogy consistently grade from a bright green outer rim to a yellowish brown inner core. Carbonate is a later vesicle phase and partly replaces earlier-formed smectites. Segregation vesicles are relatively common in the coarser-grained intersertal textured segments with welldefined lunes of finely crystalline residual melt (Plate 1, Fig. 6).

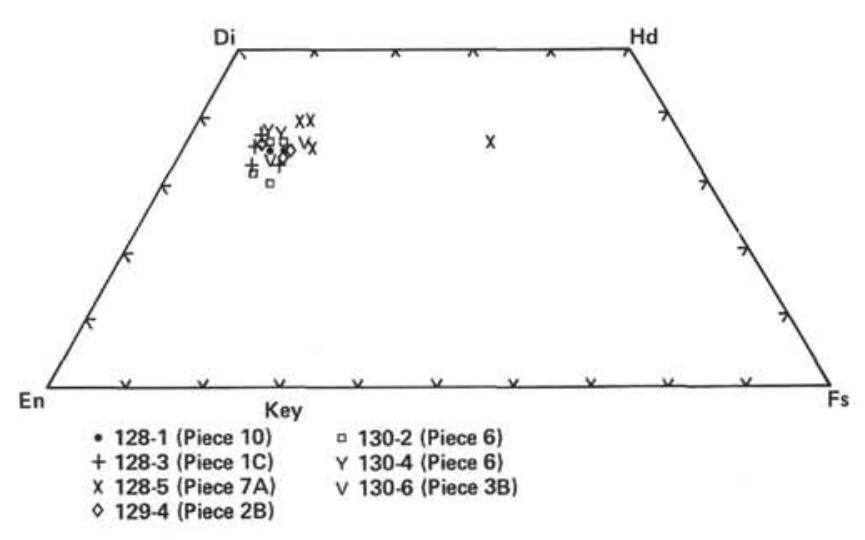

Figure 1. Pyroxene quadrilateral showing representative groundmass clinopyroxene compositions from basalts of Hole 534A by coresection (piece). 
Table 2. Representative clinopyroxene compositions analyzed by microprobe.

\begin{tabular}{|c|c|c|c|c|c|c|c|c|c|}
\hline \multirow{2}{*}{$\begin{array}{c}\text { Analysis No. } \\
\text { Sample }\end{array}$} & 1 & 2 & 3 & 4 & 5 & 6 & 7 & 8 & 9 \\
\hline & $\begin{array}{l}534 \mathrm{~A}-128-1 \\
\text { (Piece 10) }\end{array}$ & $534 \mathrm{~A}-128-3$ & (Piece 1C) & $534 \mathrm{~A}-128-5$ & (Piece 7A) & $534 \mathrm{~A}-129-4$ & (Piece 2B) & $534 \mathrm{~A}-130-6$ & (Piece 3B) \\
\hline $\mathrm{SiO}_{2}$ & 53.24 & 52.44 & 52.95 & 48.77 & 53.11 & 53.56 & 52.48 & 51.40 & 53.41 \\
\hline $\mathrm{TiO}_{2}$ & 0.28 & 0.22 & 0.18 & 1.25 & 0.42 & 0.17 & 0.36 & 0.45 & 0.26 \\
\hline $\mathrm{Al}_{2} \mathrm{O}_{3}$ & 4.20 & 3.00 & 2.91 & 11.20 & 2.34 & 2.50 & 3.29 & 4.28 & 2.55 \\
\hline $\mathrm{Cr}_{2} \mathrm{O}_{3}$ & 0.36 & 0.67 & 0.58 & 0.00 & 0.00 & 0.18 & 0.18 & 0.12 & 0.47 \\
\hline $\mathrm{FeO}^{-}$ & 6.61 & 5.81 & 6.36 & 17.29 & 10.13 & 8.46 & 8.52 & 9.53 & 7.81 \\
\hline $\mathrm{MnO}$ & 0.21 & 0.17 & 0.16 & 0.23 & 0.21 & 0.24 & 0.23 & 0.27 & 0.17 \\
\hline $\mathrm{MgO}$ & 17.83 & 18.51 & 20.17 & 6.23 & 17.14 & 18.51 & 18.10 & 17.09 & 19.36 \\
\hline $\mathrm{CaO}$ & 16.63 & 18.23 & 16.18 & 12.61 & 17.38 & 17.01 & 17.30 & 17.42 & 16.48 \\
\hline $\mathrm{Na}_{2} \mathrm{O}$ & 0.37 & 0.00 & 0.00 & 1.69 & 0.00 & 0.00 & 0.00 & 0.00 & 0.00 \\
\hline $\mathrm{K}_{2} \mathrm{O}$ & 0.04 & 0.00 & 0.00 & 0.4 & 0.00 & 0.00 & 0.00 & 0.00 & 0.00 \\
\hline Total & 99.77 & 99.05 & 99.49 & 99.31 & 100.73 & 100.63 & 100.46 & 100.56 & 100.51 \\
\hline $\mathrm{Si}$ & 1.933 & 1.925 & 1.927 & 1.848 & 1.945 & 1.946 & 1.916 & 1.886 & 1.937 \\
\hline $\mathrm{Al}^{\mathrm{iv}}$ & 0.067 & 0.075 & 0.073 & 0.152 & 0.055 & 0.054 & 0.084 & 0.114 & 0.063 \\
\hline $\mathrm{Al}^{\mathrm{vi}}$ & 0.113 & 0.055 & 0.052 & 0.348 & 0.046 & 0.053 & 0.057 & 0.071 & 0.046 \\
\hline $\mathrm{Ti}$ & 0.008 & 0.006 & 0.005 & 0.036 & 0.012 & 0.005 & 0.010 & 0.012 & 0.007 \\
\hline $\mathrm{Cr}$ & 0.010 & 0.019 & 0.017 & 0.000 & 0.000 & 0.005 & 0.005 & 0.003 & 0.013 \\
\hline $\mathrm{Fe}$ & 0.201 & 0.178 & 0.194 & 0.548 & 0.310 & 0.257 & 0.260 & 0.292 & 0.237 \\
\hline $\mathrm{Mn}$ & 0.006 & 0.005 & 0.005 & 0.007 & 0.007 & 0.007 & 0.007 & 0.008 & 0.005 \\
\hline $\mathrm{Mg}$ & 0.965 & 1.013 & 1.094 & 0.352 & 0.936 & 1.003 & 0.985 & 0.935 & 1.046 \\
\hline $\mathrm{Ca}$ & 0.647 & 0.717 & 0.631 & 0.512 & 0.682 & 0.662 & 0.677 & 0.685 & 0.640 \\
\hline $\mathrm{Na}$ & 0.026 & 0.000 & 0.00 & 0.124 & 0.000 & 0.00 & 0.00 & 0.000 & 0.000 \\
\hline $\mathrm{K}$ & 0.002 & 0.000 & 0.000 & 0.002 & 0.000 & 0.000 & 0.000 & 0.000 & 0.000 \\
\hline Wo & 35.7 & 37.6 & 32.9 & 36.3 & 35.4 & 34.5 & 35.2 & 35.8 & 33.3 \\
\hline En & 53.2 & 53.1 & 57.0 & 24.9 & 48.5 & 52.2 & 51.3 & 48.9 & 54.4 \\
\hline Fs & 11.1 & 9.3 & 10.1 & 38.8 & 16.1 & 13.3 & 13.5 & 15.3 & 12.3 \\
\hline
\end{tabular}

\section{ALTERATION}

Smectites, carbonate, and quartz are the main alteration phases replacing the fine groundmass and microphenocryst phases, and extensively altering the originally glassy mesostasis. Groundmass plagioclase and clinopyroxene crystals are fractured, resulting in fracture-filling and replacement by clays. In contrast, plagioclase microphenocrysts are usually quite fresh and unfractured.

\section{BASALT CHEMISTRY}

Four whole-rock analyses of basalts from Hole 534A are presented in Table 3 . The samples are compositionally similar, and significant chemical differences were not observed with depth. The basalts are typical midocean ridge tholeiites with low $\mathrm{TiO}_{2}$ (less than $1 \%$ ); low total alkalies (less than $3.0 \%$ ); low $\mathrm{K}_{2} \mathrm{O} / \mathrm{Na}_{2} \mathrm{O}$ ratios; and low $\mathrm{P}_{2} \mathrm{O}_{5}$ (less than $0.1 \%$ ). However, extensive alteration is indicated by high total water $(4.5-6.5 \%)$ and $\mathrm{CO}_{2}$ (up to $1.1 \%$ ), which significantly reduce the other major oxides by dilution. Consequently, $\mathrm{H}_{2} \mathrm{O}^{-}$is not included in the totals and is reported separately. High $\mathrm{Fe}_{2} \mathrm{O}_{3} / \mathrm{FeO}$ ratios of 0.6 or greater indicate extensive oxidation of the rocks during alteration. The effects of low temperature alteration may also include leaching of $\mathrm{Ca}^{+2}, \mathrm{Mg}^{+2}$, and addition of $\mathrm{SiO}_{2}, \mathrm{Fe}, \mathrm{Al}$, and $\mathrm{K}$.

CIPW calculations $\left(\mathrm{H}_{2} \mathrm{O}, \mathrm{CO}_{2}\right.$-free) suggest that the basalts are saturated tholeiites with normative diopside, hypersthene, and quartz of up to $1.2 \%$ in analyses of Samples 534A-128-5, 73-81 cm and 534A-130-2, 90-96 $\mathrm{cm}$. Because CIPW calculations are sensitive to changes in $\mathrm{Fe}_{2} \mathrm{O}_{3} / \mathrm{FeO}$ ratio, the analyses have been recalculated with the reduction of $\mathrm{Fe}_{2} \mathrm{O}_{3}$ to give values of $1.50 \%$, which is in the range of fresh tholeiitic rocks (Shido and Miyashiro, 1971). Following the application of this cor-
Table 3. Chemical composition and CIPW norm of basalt from Hole 534A.

\begin{tabular}{|c|c|c|c|c|}
\hline \multirow{2}{*}{$\begin{array}{l}\text { Analysis No. } \\
\text { Sample }\end{array}$} & 1 & 2 & 3 & 4 \\
\hline & $\begin{array}{l}534 \mathrm{~A}-128-1 \\
121-131 \mathrm{~cm}\end{array}$ & $\begin{array}{c}534 \mathrm{~A}-128-5 \\
21-26 \mathrm{~cm}\end{array}$ & $\begin{array}{c}534 \mathrm{~A}-128-5 \\
73-81 \mathrm{~cm}\end{array}$ & $\begin{array}{c}534 \mathrm{~A}-130-2 \\
90-96 \mathrm{~cm}\end{array}$ \\
\hline $\mathrm{SiO}_{2}$ & 47.51 & 47.73 & 48.39 & 48.99 \\
\hline $\mathrm{TiO}_{2}$ & 0.93 & 0.87 & 0.96 & 0.90 \\
\hline $\mathrm{Al}_{2} \overline{\mathrm{O}}_{3}$ & 15.13 & 14.63 & 14.60 & 14.87 \\
\hline $\mathrm{Fe}_{2} \mathrm{O}_{3}$ & 4.39 & 4.18 & 5.57 & 4.48 \\
\hline $\mathrm{FeO}$ & 7.31 & 7.06 & 6.40 & 7.48 \\
\hline $\mathrm{MnO}$ & 0.19 & 0.22 & 0.14 & 0.12 \\
\hline $\mathrm{MgO}$ & 8.90 & 8.17 & 8.78 & 8.36 \\
\hline $\mathrm{CaO}$ & 9.70 & 12.16 & 11.53 & 10.81 \\
\hline $\mathrm{Na}_{2} \mathrm{O}$ & 2.10 & 2.02 & 2.05 & 2.02 \\
\hline $\mathrm{K}_{2} \mathrm{O}$ & 0.31 & 0.13 & 0.23 & 0.52 \\
\hline $\mathrm{P}_{2} \mathrm{O}_{5}$ & 0.08 & 0.09 & 0.09 & 0.08 \\
\hline $\mathrm{V}_{2} \mathrm{O}_{5}$ & 0.06 & 0.0 & 0.0 & 0.0 \\
\hline $\mathrm{Cr}_{2} \mathrm{O}_{5}$ & 0.08 & 0.01 & 0.0 & 0.0 \\
\hline $\mathrm{NiO}$ & 0.0 & 0.02 & 0.0 & 0.0 \\
\hline $\mathrm{CO}_{2}$ & 0.33 & 1.06 & 0.54 & 0.24 \\
\hline $\mathrm{H}_{2} \mathrm{O}$ & 2.53 & 1.66 & 1.51 & 1.42 \\
\hline Total & 99.55 & 100.10 & 100.79 & 100.29 \\
\hline $\mathrm{H}_{2} \mathrm{O}^{-}$ & 4.09 & 2.84 & 4.01 & 3.25 \\
\hline $\mathrm{Q}$ & 0 & 0 & 1.16 & 0.86 \\
\hline Or & 1.90 & 0.79 & 1.38 & 3.12 \\
\hline $\mathrm{Ab}$ & 18.39 & 17.57 & 17.57 & 17.33 \\
\hline An & 32.02 & 31.32 & 30.34 & 30.39 \\
\hline $\mathrm{Di}$ & 13.86 & 24.24 & 21.53 & 18.90 \\
\hline $\mathrm{Hy}$ & 25.08 & 17.79 & 17.79 & 20.89 \\
\hline Ol & 0.03 & 0.14 & 0 & 0 \\
\hline $\mathrm{Cr}$ & 0.12 & 0.02 & 0 & 0 \\
\hline $\mathrm{Mt}$ & 6.59 & 6.23 & 8.18 & 6.59 \\
\hline Il & 1.83 & 1.70 & 1.85 & 1.73 \\
\hline $\mathrm{Ap}$ & 0.19 & 0.21 & 0.21 & 0.19 \\
\hline Total & 100.00 & 100.00 & 100.00 & 100.00 \\
\hline
\end{tabular}

Note: - indicates no data available. 
rection, CIPW calculations yield normative olivine in the range of 7.7 to $10.5 \%$, which is indicative of the original undersaturated tholeitic composition of the basalts and plots in the olivine tholeiite field of the basalt tetrahedron (Yoder and Tilley, 1962). Figure 2 illustrates the normative olivine, plagioclase, pyroxene relationships in relation to the inferred olivine-plagioclase cotectic drawn by Shido and Miyashiro (1971). After reduction of their ferric iron to $1.50 \%$ and recalculation of normative minerals, the basalts plot in a tight field to the right of the cotectic within the olivine-tholeiite field. The $\mathrm{Mg} /\left(\mathrm{Mg}+\mathrm{Fe}^{2+}\right)$ ratios can be applied to indicate whether the basalts represent evolved or primitive liquids that have ratios of approximately 0.70 in equilibrium with their peridotitic source material (Ayuso et al., 1976). Because these basalts have $\mathrm{Mg} /\left(\mathrm{Mg}+\mathrm{Fe}^{2+}\right) \mathrm{ra}-$ tios between 0.58 and 0.60 , after reduction of $\mathrm{Fe}_{2} \mathrm{O}_{3}$ to $1.50 \%$ as discussed earlier, they do not represent primitive liquids but have undergone fractionation of ferromagnesium phases such as olivine and/or pyroxene resulting in higher $\mathrm{Mg} /\left(\mathrm{Mg}+\mathrm{Fe}^{2+}\right)$ ratios.

\section{SUMMARY}

The basalts of Hole 534A represent a short section of pillow lava flows of one textural and chemical type. The textural range exhibited is characteristic of basalts erupted on the seafloor at present median valley envi-

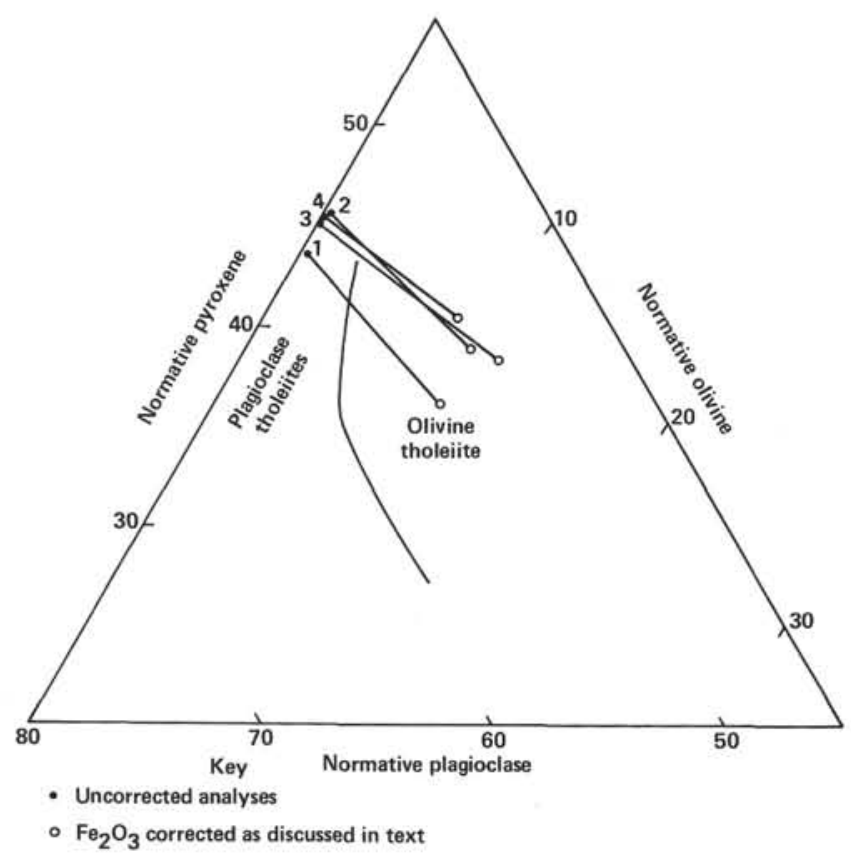

Figure 2. Normative olivine-plagioclase-pyroxene relationships in basalts from Hole 534A. (The empirically determined olivine-plagioclase cotectic is from Shido and Miyashiro [1971]. Samples 1-4 are from Table 3.) ronments. In agreement with the shipboard description, the basalts are sparsely phyric with minor amounts of plagioclase microphenocrysts in a groundmass of calcic plagioclase, clinopyroxene, iron-titanium oxides, and variable amounts of extensively altered palagonitic mesostasis. Variable degrees of alteration, mainly by green and brown smectite, carbonate, and trace amounts of quartz have affected these basalts with an observed order of preference for palagonitic mesostasis, fine-grained pyroxene and plagioclase intergrowths, clinopyroxene, and plagioclase.

Chemically the basalts of Hole 534A are typical midocean ridge tholeiites with normative olivine and hypersthene, and plot in the olivine tholeiite field of the basalt tetrahedron of Yoder and Tilley (1962). The $\mathrm{Mg} /(\mathrm{Mg}+$ $\mathrm{Fe}^{2+}$ ) ratios range from 0.60 to 0.58 , which indicate that these basalts are evolved compared to primitive mantle melts. The presence of only plagioclase microphenocrysts is indicative of plagioclase tholeiites as defined by Shido and Miyashiro (1971) on the basis of being the first phase to precipitate. However, after partial reduction of $\mathrm{Fe}_{2} \mathrm{O}_{3}$, all analyses plot within the olivine tholeiite field of the normative olivine, plagioclase, pyroxene triangle (Figure 2), which more accurately characterizes the composition of the basalts.

\section{ACKNOWLEDGMENTS}

The author is grateful for the helpful discussions with Dr. J. M. Hall, and for his financial support of this research. I wish to express my thanks to Drs. J. M. Hall and P. T. Robinson for their helpful criticism in reviewing this paper.

\section{REFERENCES}

Ayuso, R. A., Bence, A. E., and Taylor, S. R., 1976. Upper Jurassic tholeitic basalts from DSDP Leg 11. J. Geophys. Res., 81: 4305-4325.

Bryan, W. B., 1972. Morphology of quench crystals in submarine basalts. J. Geophys. Res., 77:5812-5819.

Engel, A. E. J., Engel, C. G., and Havens, R. G., 1965. Chemical characteristics of oceanic basalts and the upper mantle. Geol. Soc. Am. Bull., 76:719-734.

Huebner, J. S., 1980. Pyroxene phase equilibria at low pressure. In Prewitt, C. T. (Ed.), Pyroxenes: Reviews in Mineralogy, 7:213-288.

MacKay, R. M., 1981. Whole rock analysis using the electron microprobe (B. Sc. thesis). Dalhousie University, Halifax, Nova Scotia, Canada.

Maxwell, J. A., 1968. Rock and Mineral Analysis: New York (Interscience).

Poldervaart, A., and Hess, H. H., 1951. Pyroxenes in the crystallization of basaltic magma. J. Geol., 59:472-489.

Rucklidge, J. C., and Gasparrini, E., 1969. EMPADR VII: Toronto (Department of Geology, University of Toronto).

Sen Gupta, J. G., 1970. Determination of carbon by non-aqueous titration after combustion in a high-frequency induction furnace. Anal. Chim. Acta, 51:437-447.

Shido, F., and Miyashiro, A., 1971. Crystallization of abyssal tholeiites. Contrib. Mineral. Petrol., 31:251-266.

Yoder, H. S., Jr., and Tilley, C. E., 1962. Origin of basalt magmas: an experimental study of natural and synthetic rock systems. $J$. Petrol., 3(pt. 3):342-532.

Date of Initial Acceptance: April 15, 1982 

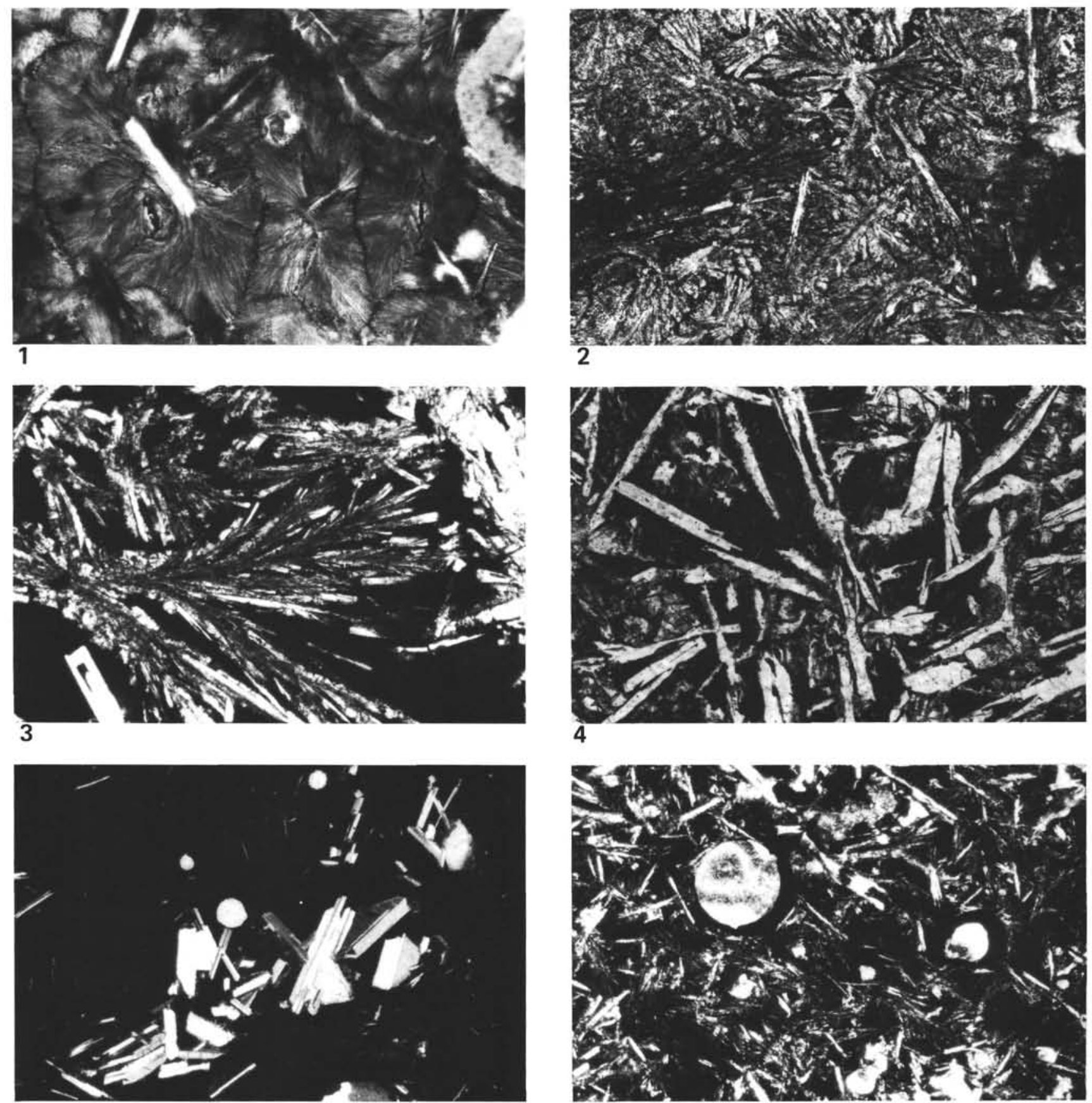

5

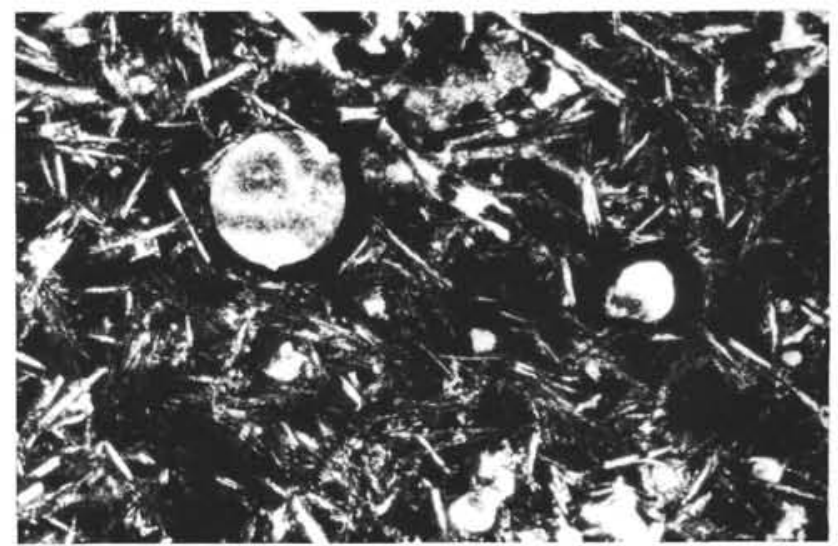

6

Plate 1. 1. Chilled margin of pillow flow, showing common coalesced variolites, and plagioclase microlites, a number of which occupy central positions within individual varioles. Sample $534 \mathrm{~A}-128-4,39-45 \mathrm{~cm}$. Length of field $-0.9 \mathrm{~mm}$. 2. Coarser textured groundmass of sheaf- and plumose-textured pyroxene intergrown with fine acicular plagioclase, and interstitial iron-titanium oxide grains. Sample 534A-129-4, 37-43 cm. Length of field $-3.4 \mathrm{~mm}$. 3. Detailed view of Fig. 2; field of view $-0.9 \mathrm{~mm}$. 4. Subophitic intergrowths of plagioclase laths and augitic clinopyroxene, with interstitial dark brown and layered palagonite containing inclusions of skeletal iron-titanium oxides. Sample 534A-128-5, 73-81 $\mathrm{cm}$. Length of field $-0.9 \mathrm{~mm}$. 5. Glomerocrystic cluster of plagioclase microphenocrysts, set in a vesicular variolitic groundmass. Sample $534 \mathrm{~A}-128-5,21-26 \mathrm{~cm}$. Length of field-3.4 mm. 6. Segregation vesicles with well developed lune, of residual ironrich melt. Sample 534A-130$5,14-21 \mathrm{~cm}$. Length of field $-3.4 \mathrm{~mm}$. 